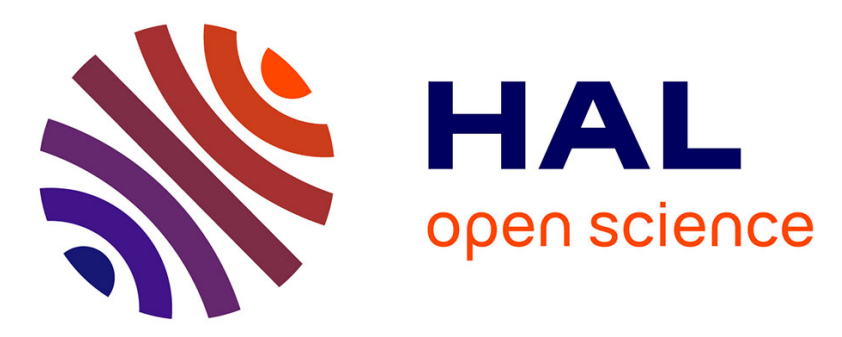

\title{
Fine-scale horizontal and vertical micro-distribution patterns of testate amoebae along a narrow Fen/Bog gradient.
}

Vincent E. J. Jassey, Genevieve Chiapusio, Edward A. D. Mitchell, Philippe Binet, Marie-Laure Toussaint, Daniel Gilbert

\section{To cite this version:}

Vincent E. J. Jassey, Genevieve Chiapusio, Edward A. D. Mitchell, Philippe Binet, Marie-Laure Toussaint, et al.. Fine-scale horizontal and vertical micro-distribution patterns of testate amoebae along a narrow Fen/Bog gradient.. Microbial ecology, 2011, 61 (2), pp.374-385. 10.1007/s00248-0109756-9 . hal-00682493v2

\section{HAL Id: hal-00682493 \\ https://hal.science/hal-00682493v2}

Submitted on 26 Mar 2012

HAL is a multi-disciplinary open access archive for the deposit and dissemination of scientific research documents, whether they are published or not. The documents may come from teaching and research institutions in France or abroad, or from public or private research centers.
L'archive ouverte pluridisciplinaire HAL, est destinée au dépôt et à la diffusion de documents scientifiques de niveau recherche, publiés ou non, émanant des établissements d'enseignement et de recherche français ou étrangers, des laboratoires publics ou privés. 
Fine-scale horizontal and vertical micro-distribution patterns of testate amoebae along a narrow fen/bog gradient

Vincent E.J. Jassey ${ }^{1 *}$, Geneviève Chiapusio ${ }^{1}$, Edward A.D. Mitchell ${ }^{2}$, Philippe Binet ${ }^{1}$, MarieLaure Toussaint ${ }^{1}$, Daniel Gilbert ${ }^{1}$

${ }^{1}$ Laboratory of Chrono-Environment UMR-CNRS 6249, University of Franche-Comté, F25211 Montbéliard cedex, France

${ }^{2}$ Laboratory of Soil Biology, University of Neuchâtel, Rue Emile-Argand 11, CH-2009

Neuchâtel, Switzerland

* Corresponding author: Vincent Jassey

E-mail address: vincent.jassey@univ-fcomte.fr

Phone: +33 381994 693, Fax : +33 381994661

Date of submission: $2010,15^{\text {th }}$ June

Running headline: Micro-distribution of testate amoebae in Sphagnum 


\section{Abstract}

2 The ecology of peatland testate amoebae is well studied along broad gradient from very wet

3 (pool) to dry (hummock) micro-sites where testate amoeba are often found to respond

4 primarily to the depth to water table (DWT). Much less is known on their responses to finer-

5 scale gradients and nothing is known of their possible response to phenolic compounds,

6 which play a key role in carbon storage in peatlands. We studied the vertical $(0-3 \mathrm{~cm} ; 3-6 \mathrm{~cm}$;

$7 \quad 6-9 \mathrm{~cm}$ sampling depths) micro-distribution patterns of testate amoebae in the same

8 microhabitat (Sphagnum fallax lawn) along a narrow ecological gradient between a poor fen

9 with an almost flat and homogeneous Sphagnum carpet (fen) and a "young bog" (bog) with

10 more marked micro-topography and mosaic of poor-fen and bog vegetation. We analysed the

11 relationships between the testate amoeba data and three sets of variables (1) "chemical" ( $\mathrm{pH}$,

12 Eh potential \& conductivity), (2) "physical" (water temperature, altitude i.e. Sphagnum mat

13 microtopography \& DWT) and (3) phenolic compounds in/from Sphagnum (water-soluble

14 and primarily bound phenolics) as well as the habitat (fen/bog) and the sampling depth.

15 Testate amoeba Shannon H' diversity, equitability J of communities, and total density peaked

16 in lower parts of Sphagnum, but the patterns differed between the fen and bog micro-sites.

17 Redundancy analyses (RDA) revealed that testate amoeba communities differed significantly

18 in relation to Eh, conductivity, water temperature, altitude, water-soluble phenolics, habitat,

19 and sampling depth, but not to DWT, $\mathrm{pH}$, or primarily bound phenolics. The sensitivity of

20 testate amoebae to weak environmental gradients makes them particularly good integrators of

21 micro-environmental variations and has implications for their use in paleoecology and

22 environmental monitoring. The correlation between testate amoeba communities and the

23 concentration of water-soluble phenolic suggests direct (e.g. physiological) and/or indirect

24 (e.g. through impact on prey organisms) effects on testate amoebae, which requires further

25 research. 


\section{Introduction}

27 Testate amoebae are abundant and diverse shelled protozoa living in a wide range of habitats 28 ranging from soils, lakes, rivers, wetlands, and moss habitats [4, 13, 62]. Owing to ecological gradients and the preservation of their shells in peat and sediments, these protists are useful proxies in paleoenvironmental and ecological studies of peatland and lakes $[6,11,43]$. In Sphagnum bogs, testate amoeba community composition is generally strongly correlated to surface wetness conditions (mostly assessed by the water table depth - hereafter DWT) and water chemistry $[3,39,48,59]$.

While the relationship between testate amoebae and DWT, and a few other variables such as $\mathrm{pH}$ are well documented along broad ecological gradient (e.g. wet pools to dry hummocks, fen to bog) [26, 47], much less is known on their finer-scale responses to microenvironmental gradients. Some data suggests that testate amoebae may be highly sensitive even to subtle micro-environmental gradients. For example Mitchell et al. [40] studied the horizontal distribution patterns of testate amoeba communities in a 40x60cm almost flat mono-specific Sphagnum lawn and found spatial heterogeneity in the communities that was significantly correlated to altitude (microtopography) (despite a very short $-\mathrm{ca}$. $6 \mathrm{~cm}-$ elevation gradient). Assessing testate amoeba species-environment correlation along finescale environmental gradients is necessary to define the practical limits (i.e. the resolution) of their use as bioindicators in ecological and palaeoecological studies.

Another open question is the range of abiotic and biotic factors to which testate amoebae respond. Although many variables have been studied, DWT almost always emerges as the strongest variable despite the fact that testate amoebae are unlikely to be directly influenced by the position of the water table 10 or $30 \mathrm{~cm}$ below the level where they live [41]. Still some important potential factors have not yet been studied including peat and water chemistry beyond simple ions and elements. Sphagnum peatlands are indeed generally 
51 characterized by gradients such as nutrients (nutrient-poor ombrotrophic bogs vs. rich fens),

52 hydrology (wet hollow vs. dry hummocks) and acidity [14, 22, 23, 52]. Recently, phenolic compounds (secondary metabolites) produced by plants have been described to play an important role in the interactions of plants with their environment including microorganisms [24]. For example in humus spruce forests such compounds have been shown to cause the increase of several microbial communities (i.e. cellulose hydrolyser) and in the decrease of others (i.e. bacteria) $[56,57]$. While the production of phenolic compounds by vascular plants is well documented, few studies have addressed phenols production by non-vascular cryptogams such as Sphagnum. The role of phenolics produced by vascular plants on the functioning of the bog ecosystem is established [18], as well as the phenolics content gradient between knoll forest-peat bogs and peat bogs [16]. Possible effects of phenolics produced by Sphagnum on microorganisms, including testate amoebae, are still unknown. Sphagnum contains weakly as well as primarily bound phenolics to the cell wall [61]. The unique morphology and anatomy of Sphagnum, allows water-soluble phenols to be easily released in the Sphagnum surrounding environment. Thus the patterns of phenol concentrations at the surface of Sphagnum peatlands may contribute to creating micropatterned habitats and a range of ecological niches suitable for the establishment of diverse communities of organisms including testate amoebae $[1,12,40]$. vertical micro-distribution patterns of testate amoebae along a short ecological gradient from a Sphagnum-dominated poor fen (for simplicity hereafter referred to here as "fen") and a vegetation with mixed bog and poor fen plant elements and a more marked micro-topography 73 (hereafter referred to as "bog"). Rather than sampling contrasted microhabitats or moss species, we sampled only within macroscopically homogenous and similar Sphagnum fallax 
amoebae community structure varied along the gradient, and (2) the relationships between the testate amoeba communities and DWT, water chemistry and phenolic compound content. We hypothesized (1) that the vertical patterns of community structure would be more marked in the structurally more complex mixed Sphagnum "bog" habitat than in the more uniform poor fen, despite the fact that the sampled habitats were macroscopically identical and, (2) that phenolic compounds would explain a similar fraction of the community data structure as other more commonly studied environmental factors (i.e. altitude, DWT, water chemistry).

\section{Methods}

Sampling and laboratory analyses

The study site was an undisturbed ombrotrophic Sphagnum-dominated mire [2] situated in the Jura Mountains (The Forbonnet peatland, France, $46^{\circ} 49^{\prime} 35^{\prime \prime} \mathrm{N}, 6^{\circ} 10^{\prime} 20^{\prime}$ 'E) at an altitude of $840 \mathrm{~m}$ above sea level (Supplementary Fig. 1). Cold winters (on average of $-1.4^{\circ} \mathrm{C}$ ) and mild summers (on average of $14.6^{\circ} \mathrm{C}$ ) characterized the climate of the site. The annual mean temperature measured at the site over a one year period from November $5^{\text {th }} 2008$ to November $30^{\text {th }} 2009$ was $6.5^{\circ} \mathrm{C}$ and the annual precipitations were $1200 \mathrm{~mm}$.

Samples of Sphagnum fallax were collected from two adjacent areas (ca. $10 \mathrm{~m}$ x $12 \mathrm{~m}$ ) selected in relation to their micro-topography, vegetation and assessment of sources and decay of organic matter [15]. The first sampling area (coded "fen") is a transitional Sphagnum-dominated poor fen area, relatively flat and homogeneous, characterized by a moss cover dominated by Sphagnum fallax and by the lack of $S$. magellanicum. Vascular plants as Eriophorum vaginatum, Vaccinum oxycoccus and Andromeda polifolia were recorded in very low abundance. Scheuchzeria palustris and Carex limosa occurred outside of the studied plots. The second sampling area (coded "bog") is an open bog area with mixed vegetation, 
directly adjacent to the fen area. Patterns of hummocks with S. magellanicum, V. oxycoccos,

101 E. vaginatum, C. rostrata and Calluna vulgaris, and hollows with lawns of S. fallax and A.

102 polifolia characterized the sampling area. The terms "fen" and "bog" are used here for 103 simplicity and to denote the existence of a trophic gradient inferred from the vegetation. 104 However the "bog" sub-site represents a mosaic of poor-fen (lawns, hollows) and bog 105 (hummock) vegetation.

In each of the two sampling areas, six plots were selected in representative surfaces. Among the 12 sampling plots, the maximal distance between the two most distant plots was ca. $30 \mathrm{~m}$. On June $26^{\text {th }} 2008$, samples of $S$. fallax were collected in each plot for the study of testate amoeba communities and phenolic compounds around 10 permanent markers in each plot. The goals of this sampling design were (1) to allow for multiple sampling at the site over time (this study representing the $\mathrm{T} 0$ of a warming experiment), and (2) to obtain a composite sample from each plot and avoid any bias due to spatial heterogeneity [40]. Moreover in each 113 plots, the Eh potential, the $\mathrm{pH}$, the conductivity $(\mathrm{K})$, the water temperature (W-Temp), the 114 depth to the water table (DWT; measured in a piezometer in the centre of each plot), and the average altitude (microtopography, Alt) of the sampled plot were measured. To assess the effect of microtopography on spatial distribution patterns, the average altitude (in millimeters)

117 of the 10 permanent markers was recorded in each sampling plots using an arbitrary reference 118 [40]. The values of $\mathrm{pH}$ and conductivity were standardized to $20^{\circ} \mathrm{C}$. The conductivity caused 119 by hydrogen ions was subtracted according to Sjörs [55]. Corrected conductivity (Kcorr) was then used as a proxy for total mineral richness of the water.

Primarily bound (hereafter "bound") and water-soluble phenolic (hereafter "free") compounds were extracted and quantified from lyophilized mosses. The green section (0-6 $\mathrm{cm}$; 0 being defined as the top of the capitulum) was used for these analyses, excluding the

124 lower part where the mosses start to decay. Two methods were used to extract phenolic 
125

126

127

128

130

131

132

133

134

136

137

140

141

142

143

compounds from Sphagnum. For free phenolics, 0.05g dry weight (DW) of Sphagnum was ground in a mortar, mixed with $10 \mathrm{~mL}$ distilled water, bubbled with nitrogen and agitated on a reciprocal shaker $(15 \mathrm{rpm})$ for 3 hours and filtered. For bound phenolic compounds, $0.05 \mathrm{~g}$ DW of Sphagnum was ground in a mortar, mixed with $25 \mathrm{~mL}$ ethanol / distilled water (80/20 $\mathrm{v} / \mathrm{v}$ ) and warmed under reflux at $120^{\circ} \mathrm{C}$ for 30 minutes. This extract was filtered and evaporated by using a rotary evaporator. Finally, the dry extract was dissolved in $25 \mathrm{~mL}$ of boiling distilled water (adapted from Gallet and Lebreton [19]). The free and bound total phenolic contents were quantified with the Folin-Ciocalteau reagent and were expressed in mg equivalent gallic acid $\left(A_{760}\right)$.

For testate amoeba analysis, the Sphagnum fallax samples were cut in three levels (sampling depth): 0-3 cm (upper), 3-6 cm (intermediate), and 6-9 $\mathrm{cm}$ (lower). The samples were fixed with $20 \mathrm{~mL}$ glutaraldehyde ( $2 \%$ final concentration) and stored at $4^{\circ} \mathrm{C}$ in the dark. Testate amoebae were extracted from mosses using the following extraction method [45]: each sample was shaken for 1 min on a vortex and then pressed to extract microorganisms (first solution). The mosses were then soaked again with $20 \mathrm{~mL}$ of glutaraldehyde (2\%), shaken a second time on a vortex and pressed to extract Sphagnum leachate. The leachate was left to settle for $12 \mathrm{~h}$, after which the supernatant was added to Sphagnum and the bottom to the first solution. The process was repeated six times, and all fractions were combined to obtain a final composite sample of $40 \mathrm{~mL}$. The remaining fraction was dried at $80^{\circ} \mathrm{C}$ for $48 \mathrm{~h}$ and weighted to express testate amoeba density by gram dry weight (DW) of Sphagnum. The testate amoebae were identified and counted to a total of 150 at x200 and x400 magnification by inverted microscopy (OLYMPUS IX71) following Uthermöhl's method [60]. Testate amoebae were identified to the species level whenever possible. Only living amoebae (active only, encysted individuals were not included) were counted. 
151 Total density, species richness (S), diversity index (the Shannon index H') and equitability

152 index $(\mathrm{J})$ were calculated. Because the distributions of these data were not normal, non153 parametric Friedman tests were performed.

In all analyses, species that occurred in less than $2 \%$ of maximum density were removed from the data set to reduce the influence of rare taxa on multivariate analyses [32]. We analyzed differences among sampling depths and between the fen and bog zones (nominal variables) for the dominant testate amoeba species using a MANOVA test. For all multivariate analyses, a Hellinger transformation was applied to stabilize the variance and reduce the influence of the dominant taxa [33]. A Non-metric multidimensional

160 scaling (NMDS) was used to assess patterns of variation in testate amoeba community structure along the different segments of Sphagnum (upper, intermediate and lower segments) and between the fen and bog zones. As this analysis revealed clear differences among sampling depths and between "fen" and "bog" zones $(P<0.001)$, we further explored the species-environment correlations for the different sampling depths and in the two zones separately as well as conducting global analyses. Multiple factor analysis (MFA) was used to assess the general structure of the data and to determine the relationships among the three Hellinger-transformed testate amoeba data sets and the three environmental variables data sets (chemical, physical and phenolics) [17]. MFA was performed in two steps. Firstly, a PCA was performed on each subset, which was then 170 normalized by dividing all its elements by the first eigenvalue obtained from its PCA. 171 Secondly, the normalized subsets were assembled to form a unique matrix and a second PCA 172 was performed on this matrix. RV-coefficient (ranging from 0 to 1 ) was used to measure the 173 similarity between the geometrical representations derived from each groups of variables [51]. 174 RV-coefficients are then tested by permutations [29]. Euclidean distances of global PCA were 
175

176

177

179

180

181

182

183

184

185

186

used in MFA to perform cluster analysis according to the Ward method, and the resulting dendrogram was projected in the MFA ordination space. This analysis revealed the main differences in the structure of the data described by all biotic and abiotic subsets of variables.

We assessed the relationships among the testate amoeba communities in the upper, intermediate and lower sampling depth and the three sets of environmental variables (1) “chemical” (pH, Eh potential \& conductivity), (2) "physical": (water temperature, altitude \& DWT) and (3) phenolic compounds (bound and free). The ordination patterns of testate amoeba communities and their causal relationships to environmental data-sets were assessed using redundancy analysis (RDA) [58]. The proportion of variance explained by environmental variables was quantified using variance partitioning. Adjusted $\mathrm{R}^{2}$ were used in all RDA to estimate the proportion of explained variance [49]. The analysis was repeated with the sampling area and sampling depth data-sets transformed to presence/absence in order to reveal only testate amoeba communities differences.

All multivariate analyses were performed with the software $\mathrm{R}$ [50] using vegan [47] and FactoMineR [28] packages.

(1)

\section{Results}

\section{Environmental variables}

The range of values for the eight measured environmental variables, minimum, maximum and averages for the "fen" and "bog" areas are given in Table 1. The Eh potential and water temperature were significantly higher in the "fen" area while altitude and free phenols were significantly higher in the "bog" area $(P<0.05)$. Water $\mathrm{pH}$, conductivity, DWT and the concentration of slightly bound phenolic compounds did not differ significantly between the two areas. All environmental variables, except Kcorr, pH, DWT and altitude, were 
199

200

201

202

Testate amoeba density and diversity

203 The total density of testate amoebae increased significantly with depth in the "bog" area from 204

206 207

significantly correlated to free phenolics (Table 2) while no environmental variables were significantly correlated to primarily bound phenolics. $3.2 \times 10^{4}$ ind.g ${ }^{-1} \mathrm{DW}$ in the upper segments to respectively $7.45 \times 10^{4}$ and $10 \times 10^{4}$ ind. $\mathrm{g}^{-1}$ DW in the intermediate and lower segments $(P<0.05)$. By contrast there was no significant difference with depth in the "fen" area (average density over the three depths: $4.34 \times 10^{4}$ ind. $\left.g^{-1} \mathrm{DW}\right)$.

A total of 28 testate amoeba taxa were identified in the 36 samples analyzed. In the "bog" area, species richness did not vary among the different Sphagnum segments (on average: 15 species), while in the "fen" area species richness significantly increased between the upper segments (on average: 12 species) and the intermediate/lower segments (on average: 15 species $)(P<0.05)$. In both areas, the highest diversities were measured in the intermediate and lower segments $\left(\mathrm{H}^{\prime}=3.3\right)$, and the lowest diversity in the upper segments (“fen": $H^{\prime}=1.8$; “bog": $H^{\prime}=2.5$ ). The equitability index also demonstrated a strong dominance of some species in upper segments ("fen": $\mathrm{J}=0.5$; "bog": $\mathrm{J}=0.7$ ), while in the intermediate and lower segments the communities were more balanced (both areas: $\mathrm{J}=0.85$ ).

\section{Vertical micro-distribution}

The NMDS ordination of samples from the two sampling areas showed that testate amoeba communities differed significantly along Sphagnum segments in the two sampling areas (Fig. 
$2211 ; P<0.001)$. In the "fen" area the upper segment was clearly different from the intermediate 222 and lower segments, while in the "bog" area this difference was less marked.

In the "fen" area, the most abundant taxa in the upper segments were Archerella

224 flavum (on average $2.2 \times 10^{4}$ ind.g ${ }^{-1} \mathrm{DW}$ ) and Hyalosphenia papilio (on average $1.5 \times 10^{4}$ 225 ind.g ${ }^{-1}$ DW) (Fig. 2 and supplementary Fig. 2). The intermediate segments were characterized 226 by an increased of the abundance of Hyalosphenia elegans (on average of $8.3 \times 10^{4}$ ind.g $^{-1}$ 227 DW), Nebela tincta and Physochila griseola (both on average $3.5 \times 10^{4}$ ind.g $^{-1}$ DW), and a 228 significant decrease in the abundance of A. flavum and H. papilio. The lower segments were 229 characterized by the highest abundance of $P$. griseola (on average $1.07 \times 10^{4}$ ind.g $\mathrm{g}^{-1} \mathrm{DW}$ ) and 230 H. elegans (on average $6.5 \times 10^{4}$ ind.g ${ }^{-1} \mathrm{DW}$ ).

In the "bog" area, the most abundant taxa in the upper segments were also A. flavum 232 (on average $1.22 \times 10^{4} \mathrm{ind}^{-1} \mathrm{DW}$ ), N. tincta (on average $3.8 \times 10^{4}$ ind.g $\mathrm{g}^{-1} \mathrm{DW}$ ), H. papilio 233 (on average $3.5 \times 10^{4}$ ind.g ${ }^{-1} \mathrm{DW}$ ), and Assulina muscorum (on average $8 \times 10^{4}$ ind.g $\mathrm{g}^{-1} \mathrm{DW}$ ) 234 (Fig. 2 and supplementary Fig. 2). The intermediate segments were characterized by 235 significantly higher densities of $H$. elegans (on average $1.18 \times 10^{4}$ ind.g $^{-1} \mathrm{DW}$ ), $N$. tincta (on 236 average $1.0 \times 10^{4}$ ind.g ${ }^{-1} \mathrm{DW}$ ), Amphitrema wrightianum (on average $9.7 \times 10^{4} \mathrm{ind}^{-1} \mathrm{DW}$ ) 237 and $P$. griseola (on average $7.0 \times 10^{4}$ ind.g ${ }^{-1} \mathrm{DW}$ ) and lower density of $H$. papilio. In the 238 lower segments, the most abundant taxa were $P$. griseola (on average $2.4 \times 10^{4}$ ind.g $\mathrm{g}^{-1} \mathrm{DW}$ ) and $N$. tincta (on average $9.0 \times 10^{4}$ ind.g ${ }^{-1} \mathrm{DW}$ ).

241 Species-environment correlations

242 The multiple factor analysis (MFA) of the three environmental matrices and the three testate 243 amoeba data sets confirmed the existence of an overall division between "fen" and "bog" 244 areas (Fig. 3). The composition of testate amoebae community in the upper segments was 
245 significantly linked to the chemical data and to testate amoeba assemblages of the

246 intermediate segments (Table 3). The testate amoeba communities from the intermediate

247 segments were significantly correlated to both chemical and phenolic data. No significant

248 correlation was found between the testate amoeba communities of the lower segment and the

249 environmental data sets. These patterns are further explored in the RDAs.

In the RDA ordinations (Fig. 4a, b, c and d), the two areas were clearly separated in

251 the overall analysis as well as for each of the three sampling depths. The model explained

$25251.8 \%$ (adjusted $\mathrm{r}^{2}$ ) of the variability in testate amoeba data in the overall analysis and $27.5 \%$,

$25352.7 \%$ and $41.9 \%$ (adjusted $r^{2}$ ) of the variability in the data for the upper, intermediate and

254 lower sections respectively. In the overall RDA, testate amoeba communities in the "fen" area

255 were related to higher values of $\mathrm{Eh}, \mathrm{pH}$ and $\mathrm{W}$-temp, while testate amoeba communities in the

256 "bog" area were related to higher values of phenolics, altitude and conductivity (Fig. 4a, b, c 257 and d).

The RDA on individual environmental variables revealed that the proportion of testate amoebae data explained by each explanatory variable and the significance varied strongly among variables, between the two areas, and among the three vertical positions (Table 4). In

261 the separate RDAs on the "fen" and "bog" samples all sampling depths were significant but 262 no physical or chemical variable was found significant. Free phenolics explained a high 263 proportion of variance in the upper and intermediate Sphagnum segments.

The partial RDAs showed that chemical, physical and phenolic data sets each significantly explained, independently of the other two data sets, about $7 \%$ of the species data variance $(P=0.02-0.08)$ in the overall RDA. The proportion of variance explained by these 

$5)$.

\section{Discussion}

272 Testate amoeba density and diversity

273 The communities of testate amoeba were dominated by representative of the Amphitremidae 274 and Hyalosphenidae. This community composition is similar to the hummock fauna described 275 by Heal $[26,27]$ along a fen-bog gradient. The similarities between these surveys are not 276 surprising, and support previous studies in illustrating the cosmopolitan distribution of many 277 peatland testate amoeba morphospecies from the same habitat type [43, 64]. Density is also 278 similar to that reported in other studies on peatlands [20, 44].

Vertical micro-distribution

281 Testate amoebae reached their highest Shannon diversity and equitability in the intermediate 282 and lower Sphagnum segments. The density of some taxa also differed significantly between 283 the two sampling areas in some segments. The NMDS and RDA revealed contrasting vertical 284 patterns of the testate amoeba communities especially in the fen area. Archerella flavum, 285 Heleopera sphagni and Hyalosphenia papilio together represented between 57\% ("bog") and $28688 \%$ ("fen") of the total community in the upper segments, but much less in the intermediate 287 and lower segments. Thus in agreement with previous studies [25, 34, 35, 39, 54], 288 mixotrophic species largely dominated the community in the upper segments, while 289 heterotrophic species (e.g. P. griseola or Hyalosphenia elegans) occurred principally in the 290 intermediate and lower segments of Sphagnum in both areas. 
The vertical micro-distribution of testate amoebae in Sphagnum reflects some

292 gradients such as light, temperature, oxygen, prey organisms [35, 53]. A vertical niche 293 separation among co-generic or otherwise closely related species also appeared in both 294 sampling areas (e.g. the Amphitematidae Archerella and Amphitrema, and the 295 Hyalospheniidae Nebela, Hyalosphenia and Physochila). This would support the idea of a 296 competitive exclusion mechanism between closely related species of testate amoebae [44]. 297 Mixotrophic species preferentially colonize the uppermost segments of Sphagnum, where 298 their endosymbionts can photosynthesize [9, 25, 54]. Testate amoebae also need to find the 299 required material to build their test, and this requirement may be another constraint that 300 determines their vertical micro-distribution [35, 53]. For example, Amphitrema wrightianum 301 and Archerella flavum, two closely related mixotrophic taxa, have an ecological niche 302 separation along Sphagnum segments [25]. A. flavum produces a shell composed of self303 secreted proteinaceous material whereas A. wrightianum uses xenosomes (e.g. organic debris, 304 diatom frustules) [46]. This difference in shell construction explains the different vertical 305 distribution pattern between A. flavum (upper segments) and A. wrightianum (intermediate 306 segments) in the two sampling areas [43]. The source of material for test construction and the 307 availability of appropriate food thus appear as major regulators of the abundance and the 308 repartition of these species along Sphagnum parts [20, 25, 37]. In addition, these different 309 constraints could also be taken into account to explain some species distribution patterns 310 along micro-environmental gradients [43].

312 Species-environment correlations

313 Our results agree with earlier studies in identifying the fen/bog gradient as an important factor 314 shaping the structure of testate amoeba communities [5, 27, 28, 34, 37, 38, 63]. Indeed in the 315 "fen" habitat, A. flavum, H. sphagni and H. papilio were found in greatest abundance and 
marked the ecological transition in Sphagnum upper segments. These species are typically

317 found in habitats with high (> 95\%) soil water content $[7,30,63]$. Other species such as $N$.

318 tincta and A. muscorum described as xerophilous $[12,13]$ were more abundant in the "bog"

319 habitat. Nevertheless, DWT did not emerge as strongly correlated to testate amoeba

320 communities. The DWT gradient (ca. $3 \mathrm{~cm}$ ) may not have been long enough to emerge as a

321 significant relationship. However other factors, including altitude, temperature, Eh,

322 conductivity, and free phenolics did explain a high proportion of the species data and all of

323 these were significantly different or nearly so between the two areas. Thus although DWT

324 almost always emerges as the strongest variable explaining testate amoeba community

325 structure in Sphagnum peatlands [3, 7], other variables become more important when the

326 DWT gradient is short.

Direct gradient analysis (RDA) with single explanatory variables revealed the correlations of chemical factors (i.e. Eh and conductivity) with testate amoeba communities in upper and intermediate segments. Water chemistry is known to influence testate amoebae reproduction [25] and to contribute to changes in testate amoeba distribution [30, 42, 48], but generally strongest correlations were reported with $\mathrm{pH}$ [41, 43]. Mieczan [39] demonstrated

332 that testate amoeba in the lower section $(5-10 \mathrm{~cm})$ were influenced by a combination of 333 chemical and physical factors (DWT and total organic carbon). Chemical factors explained a 334 high proportion of the testate amoeba data in the upper and intermediate segments, and their 335 influence decreased in lower segments. Testate amoebae from the upper segments were most 336 strongly correlated with the physical variables (i.e. altitude and water temperature) while in 337 the lowest segment, of all measured variables only water temperature and altitude were 338 significant. These results illustrate how vertical gradients lead to ecological niche separations 339 in Sphagnum peatlands. 
342 Sphagnum phenolics quantified in this work were extracted either water (free phenolics) or

343 solvent (bound phenolics) and the two methods yielded different results and patterns: bound

344 phenolics did not differ along the gradient whereas water-soluble phenolics did suggesting

345 that the amount of free phenolics may respond more strongly to micro-environmental

346 conditions (e.g. moisture content of mosses). These results also suggested that different kind

347 of phenolic compounds or phenolic concentrations characterized those extract. The

348 correlation between free phenolics and testate amoeba communities was particularly clear in

349 the upper and intermediate segments that correspond to the depth sampled for total

350 polyphenol analyses $(0-6 \mathrm{~cm})$. As the upper segment constitutes most of the biomass of

351 Sphagnum mosses owing to the weight of the capitulum (top $1 \mathrm{~cm}$ ), most of the measured

352 phenols are contained in this segment. This may explain that the correlation between testate

353 amoebae and free phenols was highest in the upper segment and was also high in the

354 intermediate segment. We tentatively interpret the fact that no significant correlation was

355 observed between free or bound phenols and testate amoebae in the lower segment as an

356 indication that either the patterns of phenol concentration at that depth is not correlated with

357 that of the upper $6 \mathrm{~cm}$ or that the amoebae are more influenced by other aspects of water

358 chemistry closer to the water table. These results clearly call for a detailed analysis of

359 phenolics and testate amoebae at different depth, which could not be done at our site owing to

360 the limited amount of material that could be harvested in this long-term experiment.

Among competitive interactions, this study outlines potential chemical interaction

362 between Sphagnum and testate amoebae. Recently, phenolic compounds released by

363 Sphagnum mosses (e.g. p-hydroxyl phenolics) have been shown to possess antibacterial

364 activity [36]. Thus it is possible that free phenolic compounds play a role in testate amoeba 365 assemblages due to their selective positive or negative effects. Although results do not allow 
to drawing any conclusions on a possible direct (e.g. physiological) and/or indirect (e.g.

367 through impact on prey organisms) effect of phenolics on testate amoeba communities, they

368 raise the issue of the possible role of such compounds. An experimental approach to test such

369 effects is necessary.

371 Conclusions

372 In this study we explored the community patterns and species-environment relationships of

373 testate amoebae living in Sphagnum fallax along a narrow ecological gradient from a poor fen

374 (homogeneous Sphagnum carpet) to a "young bog" (mosaic of poor fen and bog microsites).

375 In agreement with our hypotheses we observed differences between the two sampled habitats

376 and a vertical stratification of communities. These results illustrate how strongly microbial

377 communities respond even to short ecological gradients in Sphagnum-dominated peatlands.

378 The analysis of testate amoebae from three Sphagnum segments allowed us to explore the

379 detailed patterns of species-environment relationships at the time of sampling and showed

380 that slight environmental variations (e.g. altitude and related variables) are significant at the 381 microbial level. This study therefore confirmed that testate amoebae are sensitive to 382 environmental gradients at a very fine scale [40]. The importance of temporal patterns also 383 would deserve more attention. Indeed, the location and size of different microhabitats and 384 related communities in Sphagnum peatlands are not stable over time [8] and this is clearly 385 also true for testate amoeba assemblages as attested by the limited existing data on seasonal 386 patterns [62] as well as the changes documented in numerous palaeoecological records [10].

387 Understanding environmental controls on testate amoebae communities at these finer spatial 388 and temporal scales is key to improving our ability to interpret the high-resolution fossil 389 testate amoeba records in peatlands that is starting to being produced [31]. This will require 
both further detailed descriptive studies as well as manipulative experiments using biotic

391 (phenols) and abiotic data and aiming to determine which factors influence testate amoebae and what the mechanisms are.

393

\section{Acknowledgments}

395

This research is a contribution of the ANR PEATWARM project (Effect of moderate warming on the functioning of Sphagnum peatlands and their function as carbon sink). PEATWARM is supported by the French National Agency for Research under the "Vulnerability: Environment_Climate" Program (ANR-07-VUL-010). Further funding to V. Jassey by the Franche-Comté Region and to E. Mitchell by Swiss National Science Foundation (grants no: 205321-109709/1 and 205321-109709/2) is kindly acknowledged. We thank Michal Hajek and the two anonymous reviewers for their fruitful comments.

\section{References}

1. Andrus RE (1986) Some aspects of Sphagnum ecology. Some aspects of Sphagnum ecology. Can J Bot 64: 416-426

2. Bailly G (2005) Suivi floristique de la tourbière vivante de Frasne. Internal report from the Regional Natural Reserve of Le Forbonnet peatland.

3. Bobrov AA, Charman DJ, Warner BG (1999) Ecology of testate amoebae (Protozoa : Rhizopoda) on peatlands in western Russia with special attention to niche separation in closely related taxa. Protist 150: 125-136

4. Booth RK (2001) Ecology of testate amoebae (Protozoa) in two lake superior coastal wetlands: Implications for paleoecology and environmental monitoring. Wetlands 21: 564-576

5. Booth RK (2002) Testate amoebae as paleoindicators of surface-moisture changes on Michigan peatlands: modern ecology and hydrological calibration. J Paleolimnol 28: 329-348

6. Booth RK, Notaro M, Jackson ST, Kutzbach JE (2006) Widespread drought episodes in the western Great Lakes region during the past 2000 years: Geographic extent and potential mechanisms. Earth Plan Sc Let 242: 415-427

7. Booth RK, Sullivan ME, Sousa VA (2008) Ecology of testate amoebae in a North 
Carolina pocosin and their potential use as environmental and paleoenvironmental indicators. Ecoscience 15: 277-289

8. Breeuwer A, Heijmans M, Gleichman M, Robroek BJM, Berendse F (2009) Response of Sphagnum species mixtures to increased temperature and nitrogen availability. Plant Ecol 204: 97-111

9. Chacharonis P (1956) Observations on the ecology of protozoa associated with Sphagnum. J Prot, p 11

10. Charman DJ (2001) Biostratigraphic and palaeoenvironmental applications of testate amoebae. Quat Sc Rev 20: 1753-1764

11. Charman DJ, Blundell A, Chiverrell RC, Hendon D, Langdon PG (2006) Compilation of non-annually resolved Holocene proxy climate records: stacked Holocene peatland palaeo-water table reconstructions from northern Britain. Quat Sc Rev 25: 336-350

12. Charman DJ, Blundell A, Members A (2007) A new European testate amoebae transfer function for palaeohydrological reconstruction on ombrotrophic peatlands. J Quat Sc 22: 209-221

13. Charman DJ, Warner BG (1992) Relationship between Testate amoebae (Protozoa, Rhizopoda) and microenvironmental parameters on a forested peatland in Northeastern Ontario. Can J Zool 70: 2474-2482

14. Clymo RS (1973) Growth of Sphagnum - some effects of environment. J Ecol 61: 849-869

15. Delarue F, Laggoun-Défarge F, Disnar JR, Lottier N, Gogo S (2010) Organic matter sources and decay assessment in a Sphagnum-dominated peatland (Le Forbonnet, Jura Mountains, France): impact of moisture conditions. Biogeochem. (In press)

16. Djurdjevic L, Dinic A, Mitrovic M, Pavlovic P, Tesevic V (2003) Phenolic acids distribution in a peat of the relict community with Serbian spruce in the Tara Mt. forest reserve (Serbia). Eur J Soil Biol 39: 97-103

17. Escofier B, Pages J (1994) Multiple factor-analysis (afmult package). Comp Stat Dat Anal 18: 121-140

18. Freeman C, Ostle N, Kang H (2001) An enzymic 'latch' on a global carbon store - A shortage of oxygen locks up carbon in peatlands by restraining a single enzyme. Nature 409: 149-149

19. Gallet C, Lebreton P (1995) Evolution of phenolic patterns in plants and associated litters and humus of a mounatin forest ecosystem. Soil Biol Biochem 27: 157-165

20. Gilbert D, Mitchell EAD (2006) Microbial diversity in Sphagnum peatlands. In : Martini IP, Matinez Cortizas A, Chesworth W (eds) Peatlands : basin evolution and depository of records on global environmental and climatic changes. pp. 287-318

21. Gilbert D, Mitchell EAD, Amblard C, Bourdier G, Francez AJ (2003) Population dynamics and food preferences of the testate amoeba Nebela tincta major-bohemicacollaris complex (Protozoa) in a Sphagnum peatland. Acta Protozoo 42: 99-104

22. Hajek T, Beckett RP (2008) Effect of water content components on desiccation and recovery in Sphagnum mosses. Ann Bot 101: 165-173

23. Hajkova P, Hajek M (2004) Bryophyte and vascular plant responses to base-richness and water level gradients in Western Carpathian Sphagnum-rich mires. Folia Geobot 
24. Hättenschwiler S, Vitousek PM (2000) The role of polyphenols in terrestrial ecosystem nutrient cycling. Tree 15: 238-243

25. Heal OW (1962) Abundance and microdistribution of testate amoebae (Protozoa:

26. Heal OW (1964) Observations on the seasonal and spatial-distribution of testacea

27. Heal OW (1961) The Distribution of Testate Amoebae (Rhizopoda: Testaecea) in

28. Husson F, Josse J, Lê S, Mazet J (2009) FactoMineR: Factor Analysis and Data Mining with $\mathrm{R}$. $\mathrm{R}$ package, version 1.12 http://CRAN.Rproject.org/package=FactoMineR, City

29. Josse J, Pages J, Husson F (2008) Testing the significance of the RV coefficient. Comp Stat Data Anal 53: 82-91

30. Lamentowicz M, Mitchell EAD (2007) Testate amoebae as ecological and palaeohydrological indicators in peatlands - The Polish experience. In: Okruszko, T, Maltby, E, Szatylowicz, J, Swiatek, D, Kotowski, W (eds.) Wetlands: Monitoring, Modelling and Management, pp. 85-90

31. Lamentowicz M, Van der Knaap W, Lamentowicz L, Van Leeuwen JFN, Mitchell EAD, Goslar T, Kamenik C (2010) A near-annual palaeohydrological study based on testate amoebae from a sub-alpine mire: surface wetness and the role of climate during the instrumental period. J Quat Sc 25: 190-202

32. Lavoie I, Dillon PJ, Campeau S (2009) The effect of excluding diatom taxa and reducing taxonomic resolution on multivariate analyses and stream bioassessment. Ecol Ind 9: 213-225

33. Legendre P, Gallagher ED (2001) Ecologically meaningful transformations for ordination of species data. Oecologia 129: 271-280

34. Mazei YA, Tsyganov AN, Bubnova OA (2007) Structure of a community of testate amoebae in a Sphagnum dominated bog in upper sura flow (Middle Volga Territory). Biol Bul 34: 382-394

35. Meisterfeld R (1977) Horizontal and Vertical distribution of Testacea (RhizopodaTestacea) in Sphagnum. Archiv Hydrobiol 79: 319-356

36. Mellegard H, Stalheim T, Hormazabal V, Granum PE, Hardy SP (2009) Antibacterial activity of sphagnum acid and other phenolic compounds found in Sphagnum papillosum against food-borne bacteria. Let Appl Microb 49: 85-90

37. Mieczan T (2007a) Epiphytic protozoa (testate amoebae and ciliates) associated with Sphagnum in peatbogs: Relationship to chemical parameters. Polish J Ecol 55: 79-90

38. Mieczan T (2007b) Seasonal patterns of testate amoebae and ciliates in three peatbogs: relationship to bacteria and flagellates (Poleski National Park, Eastern Poland). Ecohyd Hydrobiol 7: 296-305

39. Mieczan T (2009) Ecology of testate amoebae (Protists) in Sphagnum peatlands of eastern Poland: Vertical micro-distribution and species assemblages in relation to environmental parameters. Int J Limn 45: 41-49 
40. Mitchell EAD, Borcard D, Buttler AJ, Grosvernier P, Gilbert D, Gobat JM (2000a) Horizontal distribution patterns of testate amoebae (Protozoa) in a Sphagnum magellanicum carpet. Microb Ecol 39: 290-300

41. Mitchell EAD, Buttler AJ, Warner BG, Gobat JM (1999) Ecology of testate amoebae (Protozoa : Rhizopoda) in Sphagnum peatlands in the Jura mountains, Switzerland and France. Ecoscience 6: 565-576

42. Mitchell EAD, Buttler A, Grosvernier P, Rydin H, Albinsson C, Greenup AL, Heijmans M, Hoosbeek MR, Saarinen T (2000b) Relationships among testate amoebae (Protozoa), vegetation and water chemistry in five Sphagnum-dominated peatlands in Europe. New Phytol 145: 95-106

43. Mitchell EAD, Charman DJ, Warner BG (2008) Testate amoebae analysis in ecological and paleoecological studies of wetlands: past, present and future. Biodiv Conserv 17: 2115-2137

44. Mitchell EAD, Gilbert D (2004) Vertical micro-distribution and response to nitrogen deposition of testate amoebae in Sphagnum. J Euk Microb 51: 480-490

45. Nguyen-Viet H, Bernard N, Mitchell EAD, Badot PM, Gilbert D (2008) Effect of lead pollution on testate amoebae communities living in Sphagnum fallax: An experimental study. Ecotoxi Env Safe 69: 130-138

46. Ogden CG (1984) Shell structure of some testate amoebas from britain (protozoa, rhizopoda). J Nat Hist 18: 341-361

47. Oksanen J, Blanchet G, Kindt R, Legendre P, O'Hara RG, Simpson GL, Solymos P, Stevens MHH, Wagner H (2010) vegan: Community Ecology Package. R package version 1.17-1. http://CRAN.R-project.org/package=vegan

48. Opravilova V, Hajek M (2006) The variation of testacean assemblages (Rhizopoda) along the complete base-richness gradient in fens: A case study from the Western Carpathians. Acta Protozoo 45: 191-204

49. Peres-Neto PR, Legendre P, Dray S, Borcard D (2006) Variation partitioning of species data matrices: Estimation and comparison of fractions. Ecology 87: 2614-2625

50. R Development Core Team (2008) R: A language and environment for statistical computing. R Foundation for Statistical Computing, http://CRAN.R-project.org

51. Robert P, Escoufier Y (1976) Unifying tool for linear multivariate statistical-methods - rv-coefficient. J Royal Stat Soc Series C-Applied Statistics 25: 257-265

52. Rydin H, Jeglum JK (2006) The Biology of peatlands. In:The Biology of peatlands, Oxford University Press, pp. 354

53. Schönborn W (1963) Die Stratigraphie lebender Testaceen im Sphagnetum der Hochmoore. Limnologica 1: 315-321

54. Schönborn W (1965) Untersuchungen über die Zoochlorellen-Symbiose der Hochmorr-Testacean. Limnologica 3: 173-176

55. Sjörs H (1952) On the relation between vegetation and electrolytes in north Swedish mire waters. Oikos 2:241-258

56. Souto XC, Bolano JC, Gonzalez L, Reigosa MJ (2001) Allelopathic effects of tree species on some soil microbial populations and herbaceous plants. Biol Planta 44: 269-275 
57. Souto XC, Chiapusio G, Pellissier F (2000) Relationships between phenolics and soil microorganisms in spruce forests: Significance for natural regeneration. J Chem Ecol 26: $2025-2034$

58. Ter Braak C, Simlauer P (1998) Canoco reference manual and user's guide to canoco for windows, software for canoco community ordination (version 4). In: Canoco reference manual and user's guide to canoco for windows, software for canoco community ordination (version 4), pp. 31-145

59. Tolonen K, Warner BG, Vasander H (1992) Ecology of Testaceans (Protozoa, Rhizopoda) in mires in Southern Finland. 1. Autoecology. Archiv Protist 142: 119138

60. Utermölh H (1958) Zur vervollkommnung der quantative phytoplankton-methodik. Mitteilungen aus Institut Verhein Limnologie 9: 1-38

61. Verhoeven JTA, Liefveld WM (1997) The ecological significance of organochemical compounds in Sphagnum. Acta Bot Neerl 46: 117-130

564 62. Warner BG (1987) Abundance and diversity of Testate Amoebae (Rhizopoda, Testacea) in Sphagnum peatlands in Southwestern Ontario, Canada. Archiv Protist 133: 173-189

567 63. Warner BG, Asada T, Quinn NP (2007) Seasonal influences on the ecology of testate Amoebae (Protozoa) in a small Sphagnum peatland in Southern Ontario, Canada. Microb Ecol 54: 91-100

64. Yang J, Zhang WJ, Shen YF (2009) Relationships between Testate Amoebae Assemblages (Protozoa) and Geographic Factors in Yunnan Plateau Lakes, China. J Fresh Ecol 24: 437-443 
575

576 Table 1. Environmental variables measured in the "fen" and "bog" sampling areas in Le

577 Forbonnet mire (French Jura) $(\mathrm{n}=12$, average \pm S.E).

578

579 Table 2. Non-parametric correlation matrix of measured environmental variables along the 580 "fen"/"bog" transition of Le Forbonnet mire.

581

582 Table 3. RV-coefficients (below diagonal) and corresponding $P$-values (above diagonal)

583 among the six groups of variables used in the MFA of the Forbonnet peatland. Significant 584 coefficients appear in bold.

585

586 Table 4. Summary of RDA on testate amoebae and environmental variables from Le

587 Forbonnet mire (France): fraction of variance explained and significance of individual 588 variables taken alone.

589

590 Table 5. Summary RDA and variance partitioning on testate amoebae and environmental 591 variables data from Le Forbonnet mire (France). 


\section{Figures}

594 Figure 1. (a) The two primary axes of the 3-dimensional NMDS ordination of testate amoebae

595 communities in the "bog" area from Le Forbonnet mire (France) $(\mathrm{n}=18$, final stress $=4.1)$.

596 The solution represents $75 \%$ of the variability in the data, with axes 1,2 and 3 representing

597 respectively $43 \%, 18 \%$ and $13 \%$. Samples are coded by sampling area with open symbols. (b)

598 The two primary axes of the 3-dimensional NMDS ordination of testate amoebae

599 communities in the "fen" area $(n=18$, final stress $=2.4)$. The solution represents $84 \%$ of the

600 variability in the data, with axes 1, 2 and 3 representing respectively 55\%, 19\% and $10 \%$.

601 Samples are coded by sampling area with filled symbols.

602

603 Figure 2. Distribution maps of total testate amoeba abundance and of dominant testate

604 amoeba taxa in Sphagnum fallax from the two sampling areas in Le Forbonnet mire (France).

$605 \mathrm{~A}=$ upper $(0-3 \mathrm{~cm}) \mathrm{B}=$ intermediate $(3-6 \mathrm{~cm})$ and $\mathrm{C}=$ lower $(6-9 \mathrm{~cm})$ segments. $\mathrm{X}$ and $\mathrm{Y}$ axes

606 correspond to GPS data converted into Lambert 2 references. Dot sizes are directly

607 proportional to the number of individuals per gram DW in the samples and are comparable 608 among maps.

609

610 Figure 3. Multiple factor analysis of the three testate amoeba communities (Hellinger-

611 transformed) and environmental (chemical, physical and phenolics) data sets from the

612 Forbonnet peatland. Projection of the MFA axes 1 and 2 with the result of a hierarchical

613 agglomerative clustering (grey lines), obtained by the Ward method on the Euclidean distance

614 matrix between MFA site scores, showing two main groups of sampling plots (open symbols

615 = "fen", filled symbols = "bog"). Sampling plots are indicated by F ("fen") or B ("bog")

616 followed by a number. 
617 Figure 4. Redundancy analyses biplots (axes 1 and 2) of testate amoeba data from Le

618 Forbonnet mire (France) in upper (a), intermediate (b) and lower (c) Sphagnum segments, and 619 the overall data set (d). Sampling areas are coded with open symbol for the "fen" area and 620 with filled symbol for the "bog" area. Samples are indicated as follows: circles = upper 621 segments, squares $=$ intermediate segments, triangles $=$ lower segments. F_phe : free 622 phenolics; B_phe : bound phenolics; W-temp: water temperature; Alt: average altitude 623 (microtopography) of the sampled plot; Kcorr: conductivity. 
626

627 Supplementary Figure 1. Location of the Forbonnet peatland with inset showing the location 628 of the sampling areas.

629

630 Supplementary Figure 2. Vertical micro-distribution of selected testate amoeba taxa in the 631 two sampling areas (average \pm S.E) (circles: "bog" area; triangles: "fen" area). Asterisks 632 indicate significant differences between the sampling areas $(P<0.05)$. Different letters 633 indicate significant differences among Sphagnum sections $(P<0.05)$. 